\title{
Influence of Information Technology on Personnel Management in Nigeria
}

\author{
Cross Ogohi Daniel
}

Research Scholar

\author{
Departments of Public Administration and Banking and Finance
}

Nile University of Nigeria

Abuja, Nigeria

\begin{abstract}
This study is to examine the influence of information technology on personnel management. To determine the extent of which application of information technology is significant on personnel management. The research method is descriptive. The study approach is based on the research questionnaire which has influenced the data generated and the pattern of the descriptive analysis presented. The researcher analyzed the data collected based on the response from the questionnaires distributed to the Staff and Management of the selected bank. Based on the findings, the following recommendations were made; Organizations should also develop effective security measures to protect their information system from deceptive aggressors. This could be done through the use of passwords, firewalls, encryption and decryption keys, digital signatures, anti-virus programs etc. The importance of information technology in organizations cannot be over highlighted because if the staffs get the right exercise, it will increase their output and customers will be satisfied.
\end{abstract}

Keywords: Information Technology, Personnel Management.

\section{INTRODUCTION}

Information technology concealments any form of technology, that is, any equipment or technique used by a company, institution or any other organization which handles information. The handling of information has an ancient history going back to the creation of "abacus" and subsequently "adding machines" and more recently the development of electronic computers with stored programme concept. The past few period since the development of electronic computers have been characterized by major development in information technology.

Information is compulsory in any organization for planning, controlling, decision making, communication, organizing, and directing. This can be attained through the use of the computer and the application of Management Information System (MIS), electronic data processing (EDP), office support system, data processing system, and decision support system and package.

In the last few years, information technology (IT) has terminated to be the private realm of specialists as managers and workers from various areas rely to an ever increasing degree on TT to realise their worries.

Information is required in any organization for planning, controlling, decision making, communication, organizing, and directing. This can be accomplished through the use of the computer and the application of Management

Information System (MIS), electronic data processing (EDP), office the role technology plays in attracting economic and business activities of both the private and public institution cannot be exaggerated. While it has opened up opportunities that would have gone undiscovered or deserted, it has saved many organizations millions of committed deception through its applications.

The use of technology now makes such technical jobs such as accounting, data processing, modelling, construction, forecasting and other services more interesting, attractive and less cumbersome The term information technology was coined in the late 1970's, to refer to the connection of computer based technology for handling information.

Information technology is the technology linked to the computerized or electronic gathering, recording, processing, retrieval, and communication of information which involves the use of digital electronic particularly the internet, cable and satellite televisions, and telephone links. It is taken to 15 include a complex network of computers and telecommunication technologies 
with their associated software and operating system. In addition to these, information technology also includes the knowledge to operate the computerized systems.

Information Technology (IT) has proved to be a substance to fundamental changes in the world's economies and societies by generates more avenues to earn income, allows access to useful information, improves the world of work and makes the world a global village. The IT industry spans broadcast, electronics and print media, computers, human resources management, telecommunications and e-commerce activities.

Reference [1] opined that the gratitude of the essential role of Information Technology (IT) for development became important in Nigeria with the formulation and support of the National Information Technology (IT) Policy in March, 2001. The formulation of the IT policy was a consultative process that brought together major IT stakeholders such as Computer Association of Nigeria (COAN) now known as Computer society of Nigeria, National Information Technology Professional Associations (NITDA), and Association of Licensed Telecommunication Companies in Nigeria (ALTCON) as well as all Nigerians in the Diaspora.

While [2] provides that IT policy has very clear-cut policy goals on the development of the national information backbone to engender seamless interconnectivity in ICT infrastructure development and personnel management in Nigeria.

According to [3] the term e-HRM was first used in the late 1990's when e-commerce was generalized the business world. EHRM is internal application of e-business techniques to add value to the managing through more operative and efficient information flow and is a way of doing HRM. As information technology improves, organizations especially banks, could manage an increasing number of HRM processes in an effective manner, thereby contributing to the accessibility of information and knowledge.

This in turn has help HRM professionals to play a considered role in achieving improved competitive advantage. This collaboration and intersection between IT and HRM leads to the emergence of HRMS a term used to describe the systems and processes at the connection between human resource management (HRM) and information technology (IT).

It merges all HRM activities and procedures with the information technology field while the programming of data processing systems progressed into standardized practices and packages of enterprise resource planning software. This has been developed since their increased visibility in the late 1990s and were largely used for administrative and data recording purposes and have presently transform into HRM supporting applications for recruitment and selection, flexible benefits, development, e-learning and so on.

\section{STATEMENT OF THE PROBLEM}

This study is put progressing because of some of the problems found in organizations that contempt the use of information technology. Pervious to the advent of information technology, most organizations function manually given rise to operational inadequacies such as; Waste of time, replication of efforts, and High cost of operations, Heavy work load on the employee, Low customer satisfaction and high process time per customer. Information collected can easily be lost because of filing system; fraudulent practices were difficult to dictate.

There are problem of interconnectivity i.e. no connection and transfer of information from one department to another. If the organizations seek to compete in the global environment (to be world class) without taking full advantage of information technology, then their determination can never be met. Thus, this research work is determined on the impact of information technology on decision making in organizations.

\section{OBJECTIVES OF THE STUDY}

The overall objective of the study is to discover the influence that information technology has on the personnel management in Nigeria.

i. To determine the level of application of information technology on personnel management.

ii. To identify the problems related with the application of information technology on personnel management.

\section{RESEARCH HYPOTHESES}

The following hypotheses form the foundations for this study;

$\mathrm{H}_{1}$ : The application of information technology has allowed your organization attain customer satisfaction.

$\mathrm{H}_{2}$ : There are problems related with the use of information technology in your organization. 


\section{RESEARCH METHOD}

This research therefore covers one selected organisation in Abuja, namely UBA, Abuja. Secondary data were attained through books, journals, and internet. Empirical works of other scholars were consulted. A simple size of 103 was obtained from the population of 140 at 5\% error tolerance and 95\% degree of freedom using Yamane's statistical formula 103(100\%) of the questionnaires distributed $90(87.3 \%)$ were returned and 10(12.7\%) were not returned. The questionnaire was designed in Likert scale format. The researchers directed a pre-test on the questionnaire to guarantee the validity of the instrument. Pearson moment product co-efficient and regression analysis were used to test the hypotheses.

\section{LITERATURE REVIEW}

\subsection{Concept of Information Technology}

The most significant development of the 20th century, which has significantly prejudiced business operations, is the emergence of the information age. The progress realised in information technology has made it achievable for information to be digitalized and could be processed and managed faster, cheaper and in mega or terabytes (Ovia, 2003).

Reference [4], see information technology as containing complex networks of computers, telecommunication systems and controlled devices. In accumulation to his views that information technology includes all mechanical and electronic devices skilled of producing, manipulating, transmitting, storing and recovering words, numbers, pictures and sounds.

Reference [5] goes further to include the knowledge to function this technology as information technology. Among today's important information technologies are computer and computer networks, telecommunication systems, broadcast and entertainment systems, document reproduction systems and satellite communication systems.

Reference [6] information technology are the computer based electronic systems that help individuals, organizations assemble, store, transmit, process and retrieve data and information.

Information technology provides the tools that enable us to operate in a borderless and lessening world. Advances in information technology stipulate the means by which to communicate electronically and access information more professionally across national borders. Information technology is not only a major influence behind the market place, but also an important strategic resource to the corporation. Organizations that cannot compare technologically in this information age will be at an aggressive disadvantage.

\subsection{Benefit of Information Technology (IT)}

1. Increase in Efficiency: Intense use of IT aromatizes and standardizes routines. HR professionals may focus less on administrative activities and more on understanding information. HR professionals may spend more time on other aspects of their jobs. Thus, HR professional can approach more information, respond the problems in a timely major from managers and employees and appraise the complex information more effectively [7]. Comparing with manual processes, reducing data errors, streamlining and fastening processes of HR practices make HRIS more advantageous [8], [9].

2. Competency Management: IT tools allow HR professionals both to influence larger candidate pool and make decision making more unbiased and effective to employ more applicable and competent candidates by means of decision making techniques in the selection and recruiting process. Improving and reducing the recruiting process increases competencies of occupants and as a result quality of works. At the same time, because of espance access eHR can be used to develop human capital of the organization effectively [10].

\subsection{Aspects of Information Technology}

i. Computer: A computer is an electronic machine which is accomplished of accepting data as input, conserving this data for later use, or immediately performing logical operation on it to produce result characterized output because the computer functions at electronic speediness and logic. It can perform large uninteresting and complex calculation with exactness and speed. With the growth and predominance of microcomputer in the eighties, personal computer (PCs) became the simulated standard for home and office use. This improved technology and production techniques resulted in their manufacture becoming an all corners market. This made the companies in Asia rapidly entered the market with their traditionally low production costs, the competition that was to drive down costs, while the fundamental components of the PC still remain the microprocessor. Microsoft now controls 85 percent of the global operating system today, which are a set of program instructions that co-ordinate the internal operations of a PC, having become completely graphical in operation.

ii. Computer Networking: Networking complicated connecting a number of computers, telecommunication and other devices together so that information and equipment can be allocated.

According to [10] Networking could be of these forms;

Wide Area Network (WAN) Wide Area Network is a network that expanses over a wide geographical area such as a city, a region, a country or even globally. 
Local Area Network (LAN) Local Area Network connects information systems and users within a much smaller area such as building, an office or a manufacturing plant.

\subsection{The roles of Information Technology}

Information Technology has had radical impacts on Information Technology users, their work and their work environments. Information Technology in its various appearances processes data, gathers information, stores collected materials, accumulates knowledge and expedites communication. In fact, Information Technology plays a role in many, if not most, of the everyday operations of today's organizations - creating new needs, causing new product development and commanding new processes

A framework for the roles of Information Technology as an initiator, a facilitator, and/or an enabler and he states that Information Technology can simulate any of the three roles, depending on the organization environment and how technology is being functional:

i. Initiator, as an initiator, Information Technology, can be defined as an agent of change or change agent. Information Technology becomes an originator as it enables people to recognize a powerful solution before even realizing or seeking the problem it may resolve.

ii. Facilitator, as a facilitator, Information Technology, can serve as something to make the workload easier.

iii. Enabler, as an enabler, Information Technology, can be defined as something that advances the ability or the necessary assist to achieve something.

\subsection{Management}

Management in simple terms means the act of getting people together to accomplish anticipated goals. It comprises planning, organizing, Resourcing, leading or directing, and controlling an organization (a group of one or more people or entities) or effort for the resolve of accomplishing a goal. Resourcing encompasses the deployment and manipulation of human resources, financial resources, technological resources, and natural resources.

Management is also seen as a process wanting the performance of a particular function. Here, management is a profession. According to the American institute of management, it is used to designate either a group of functions or the personnel who carry them out; to express either an organization's official hierarchy or the activities of men who compose it: to provide autonomy to either labour or ownership.

Management can be defined as the process of planning, organizing leading and controlling the efforts of organizational members and using all other organizational resources to achieve set goals". Further still, management involves the achievement of goals set for the organization. This means that managers of any organization a commercial bank, a university, or the Nigerian stock Exchange-try to attain specific ends. These ends are unique to each organization. The set goals, whatever it maybe to the organizations concerned, management is the process by which the goals can be attained.

\section{TEST OF HYPOTHESES}

\section{Hypothesis one}

$\mathrm{H}_{\mathrm{I}}$ : There is application of information technology has enabled your organization achieve customer satisfaction.

$\mathrm{H}_{0}$ : The is no application of information technology has enabled your organization achieve customer satisfaction

Table I: Table of correlation between effective information technology and customer satisfaction.

\begin{tabular}{|c|c|c|c|}
\hline & & $\begin{array}{c}\text { Effective } \\
\text { Information } \\
\text { Technology }\end{array}$ & $\begin{array}{c}\text { personnel } \\
\text { management }\end{array}$ \\
\hline $\begin{array}{c}\text { Effective } \\
\text { Information } \\
\text { Technology }\end{array}$ & Pearson Correlation & 1 & $.536 * *$ \\
Sig. (2-Tailed) & $\mathrm{N}$ & 200 & .000 \\
\hline $\begin{array}{c}\text { Personnel } \\
\text { Management }\end{array}$ & Pearson Correlation & $.536 * *$ & 240 \\
\hline
\end{tabular}

**. Correlation is significant at the 0.01 level (2-tailed). 
According to above calculations it is observed that amount of correlation coefficient between level of productivity and effective personnel management is equal to 53.6 per cent and considering that a significant level is less than $5 \%$. Then we can say that there is a positive relationship between effective information technology and personnel management. This implies that one percent increase in effective information technology will lead to $53.6 \%$ increase in level of personnel management

Table II: Regression analysis test of level of personnel management and information technology

\begin{tabular}{|c|c|c|c|c|}
\hline Model & R & R Square & Adjusted & Std. Error of \\
& & & R Square & the Estimate \\
\hline 1 & $.965^{\mathbf{a}}$ & .716 & .586 & 3.79952 \\
\hline
\end{tabular}

a. Predictors: (Constant), effective information technology

Regression coefficient of $\mathrm{R}=.965$ or $96.5 \%$ indicate that relationship exist between independent variables and dependent variable. The coefficient of determination $\mathrm{R}^{2}=0.716$ which show that $71.6 \%$ of variation in level of personnel management explained by effective information technology. The adjusted R-square in the table shows that the dependent variable, (level of personnel management) is affected by $58.6 \%$ by independent variable (effective information technology). It shows that effective information technology is responsible for personnel management in organisation.

Table III: Coefficients

\begin{tabular}{|c|c|c|c|c|c|}
\hline & \multicolumn{2}{|c|}{$\begin{array}{c}\text { Unstandardized } \\
\text { Coefficients }\end{array}$} & $\begin{array}{c}\text { Standardize } \\
\mathbf{d} \\
\text { Coefficients }\end{array}$ & & \\
\cline { 2 - 5 } Model & $\mathrm{B}$ & $\begin{array}{c}\text { Std. } \\
\text { Error }\end{array}$ & Beta & t & Sig. \\
\hline $\begin{array}{c}\text { (Constant) } \\
\text { effective } \\
\text { information } \\
\text { technology }\end{array}$ & 12.310 & .901 & & 13.656 & .002 \\
\end{tabular}

a. Dependent Variable: level of personnel management

The coefficient of determination for effective information technology is positive (1.056) and is highly significant (0.001) in ensuring level of productivity. The p-value of 0.000 is less than the t-statistic value of 12.426 and the standard error value of 0.085. This implies that a unit increase in effective information technology will lead to 1.056 increases in level of productivity. Therefore, the null hypothesis is rejected and alternative hypothesis accepted that there is a relationship between the effective management of materials and the level of productivity in an organization.

\section{Hypothesis two}

$\mathbf{H}_{2}$ There are problems associated with the use of information technology in your organization.

$\mathbf{H}_{\mathbf{0}}$ There are no problems associated with the use of information technology in your organization. 
International Journal of Engineering Research And Advanced Technology, Vol.5, Issue 2, February-2019

Table IV: Table of correlation between information technology and improving in an organisation

\begin{tabular}{|c|c|c|}
\hline & $\begin{array}{l}\text { information } \\
\text { technology }\end{array}$ & organisation \\
\hline $\begin{array}{cc} & \text { Pearson Correlation } \\
\text { information technology } & \text { Sig. (2-tailed) } \\
N \\
\end{array}$ & $\begin{array}{l}1 \\
200\end{array}$ & $\begin{array}{l}.473 * * \\
.000 \\
250\end{array}$ \\
\hline \begin{tabular}{cc}
\multicolumn{2}{c}{ Pearson Correlation } \\
improving the personnel management & Sig. (2-tailed) \\
N &
\end{tabular} & $\begin{array}{l}.473 * * \\
.000 \\
250\end{array}$ & $\begin{array}{l}1 \\
200\end{array}$ \\
\hline
\end{tabular}

**. Correlation is significant at the 0.01 level (2-tailed).

According to above calculations is observed that amount of correlation coefficient between information technology and improving in the personnel management is equal to 47.3 per cent and considering that a significant level is less than $5 \%$. Then we can say that there is a positive relationship between information technology and improving in the organisation. This implies that one percent increase in information technology will lead to $47.3 \%$ increase in improving in the organisation.

Table V: Regression analysis test of information technology and improving in the organisation

\begin{tabular}{|c|c|c|c|c|}
\hline \multicolumn{9}{|c|}{ Model Summary } \\
\hline \multirow{2}{*}{ Model } & R & R Square & $\begin{array}{l}\text { Adjusted } \\
\text { R Square }\end{array}$ & $\begin{array}{l}\text { Std. Error of } \\
\text { the Estimate }\end{array}$ \\
\hline 1 & $.773^{\mathrm{a}}$ & .624 & .722 & 3.96426 \\
\hline
\end{tabular}

a. Predictors: (Constant), information technology

Regression coefficient of $\mathrm{R}=.773$ or $77.3 \%$ indicate that relationship exist between independent variables and dependent variable. The coefficient of determination $\mathrm{R}^{2}=0.624$ which show that $62.4 \%$ of variation in improving the personnel management is explained by information technology. The adjusted R-square in the table shows that the dependent variable, (improving the personnel management) is affected by $72.2 \%$ by independent variable (information technology). It shows that there are positive impacts of information technology on improving the personnel management.

Table VI: Coefficients ${ }^{\text {a }}$

\begin{tabular}{|c|c|c|c|c|c|}
\hline \multirow[t]{2}{*}{ Model } & \multicolumn{2}{|c|}{$\begin{array}{c}\text { Unstandardized } \\
\text { Coefficients } \\
\end{array}$} & $\begin{array}{c}\text { Standardized } \\
\text { Coefficients }\end{array}$ & $\mathbf{t}$ & Sig. \\
\hline & B & Std. Error & Beta & & \\
\hline $1($ Constant $)$ & 15.036 & .806 & & 18.644 & .000 \\
\hline $\begin{array}{l}\text { Personnel } \\
\text { management }\end{array}$ & 1.319 & .125 & .473 & 10.520 & .000 \\
\hline
\end{tabular}

a. Dependent Variable: improving the personnel management

The coefficient of determination for information technology is positive (1.319) and is highly significant (0.000) in improving in the personnel management. The p-value of 0.000 is less than the t-statistic value of 10.520 and the standard error value of 0.125 . This implies that a unit increase in information technology will lead to 1.319 increases in improving in the personnel management. Therefore, the null hypothesis is rejected and alternative hypothesis that there are positive impacts of information technology on improving in the personnel management.

\section{CONCLUSION}

If the recommendations are implemented, one can expect to see rapid changes for the better in the way organizations businesses are carried on. This could lead to dramatic re-engineering of some management process. The focus would be on user-oriented service leverage by appropriate state of the art information technology. Since IT is continually changing, frequent Workshops/Seminars should be held to keep workers/staffs abreast of latest development. 
Advances in information technology have greatly influenced the idea and practice of organizations. For organizations, the implication is that they become more efficient and can increase their productivity with respect to the satisfaction of customer's needs. There is no doubt that advances in information technology has helped streamlined the back office operations of most organizations, improving both efficiency and leading to savings in cost. It is now possible for one staff in one department to ascertain and gather information he/she needs from another department of an organization because of interconnectivity in the organization.

\section{RECOMMENDATIONS}

Based on the findings, the following recommendations were made;

i. Organizations should also develop effective security measures to protect their information system from fraudulent attackers. This could be done through the use of passwords, firewalls, encryption and decryption keys, digital signatures, anti-virus programs etc.

ii. It will be necessary to provide an electronic mail system, which would largely eliminate the need for telex and fax communication between office locations. It is also necessary for all organization staffs to know how to use the office automation, tools like word processors, electronic spread sheets and communication tools like e-mail, data messaging and voice messaging.

iii. There is need for the computer service to be reorganized into what is called information technology (IT) departments. There should be computer Engineers that will be servicing the system when there is fault.

iv. The importance of information technology in organizations cannot be over emphasized because if the staffs get the right training, it will increase their output and customers will be satisfied.

\section{REFERENCES}

[1] David (2006), Human resource management, information technology and the competitive advantage. Academy of Management Executive. Vol.6 i2. 7-17.

[2] Broderick, R. and Boudreau, J.W (2001)., Human resource management, information technology and the competitive advantage. Academy of Management Executive. Vol. 6 i2. 7-17.

[3] Ruel, H.J.M. and Bondarouk, T.V. (2008), "Exploring the relationship between e-HRM and HRM effectiveness: lessons learned from three companies", in Martin, G., Reddington, M. and Alexander, H. (Eds), Technology, Outsourcing and HR Transformation, Butterworth Heinemann, Oxford, pp. 161-92.

[4] Hellriegel, D. Jackson, S. C. and Slocum J.W. (1999) Management, 8th Edition, Ohio, South western College Publishing. Co. pp. 682-702

[5] Ezigbo, C.A (2003) Advanced Management Theory, Enugu, Immaculate Publications Ltd.

[6] Gardner, S.D., Lepak, D.P. and Bartol, K.M. (2003) Virtual HR: The Impact of Information Technology on the Human Resource Professional, Journal of Vocational Behavior, 63/2, 159- 179.

[7] Ulrich, D., Younger, J. and Brockbank, W. (2008) The Twenty-First Century HR Organization, Human Resource Management, 47/4, 829-850.

[8] Hendrickson, A. R. (2003) Human Resource Information Systems: Backbone Technology of Contemporary Human Resources, Journal of Labor Research, 24/3, 381-394

[9] Bartol, M. K. and Martin, D.C. (1998) Management, 3rd Edition, Boston McGraw- Hill.

[10] Lin, L. H. (2011) Electronic Human Resource Management and Organizational Innovation: the Roles of Information Technology and Virtual Organizational Structure, The International Journal of Human Resource Management, 22/2, $235-257$. 